2 Dehn TCB, Clarke J, Dixon JM, Crucioli V, Greenall MJ, Lee ECG. Fine needle aspiration cytology, with immediate reporting in the outpatient diagnosis of breast cancer. Ann R Coll Surg Eng 1987;69:280-2.

3 Dixon JM, Clarke PJ, Crucioli V, Dehn TCB, Greenall M, Lee ECG. Reduction in biopsy rate in benign breast disease using fine needle aspiration cytology with immediate reporting. $B r f$ Surg 1987;74:1014-6.

4 Löfgren M, Andersson I, Bondeson L, Lindholm K. X ray guided fine needle aspiration for the cytologic diagnosis of non palpable breast lesions. Cancer 1988;61:1032-7.

5 Azavedo E, Svane E, Auer G. Stereotactic fine needle biopsy in 2,594 mammographically detected non palpable lesions. Lancet 1989; i: 1033-5.

6 Fransen S, Zajicek J. Aspiration biopsy in diagnosis of palpable lesions of the breast: critical review of 3,479 consecutive biopsies. Acta Radiol 1968;7:241-62.

7 Dixon JM, Lamb J, Anderson TJ, Nixon SJ, Forrest AMP. Fine needle aspiration cytology in relationship to clinical examination and mammography in the diagnosis of a solid breast mass. Brf Surg 1984;71:593-6.

Sickles EA, Klein DL, Goodson WH, Hunt TK. Mammography after fine needle aspiration of palpable breast masses. Am f Surg 1983;145:392-7.

Ellman R, Angeli N, Christians A, Moss S, Chamberlain J, Maguire P. Psychiatric morbidity associated with screening for breast cancer. Br $\mathcal{F}$ Cancer 1989;60:781-4.

10 Dixon JM, Lamb J, Anderson TJ. Fine needle aspiration cytology of solid breast lumps: the importance of the aspirator. Lancet 1983;ii:564.

11 Barrows GM, Anderson TJ, Lamb J, Dixon JM. Fine needle aspiration of breast cancer: relationship of clinical factors of cytology results in 689 primary malignancies. Cancer 986;58:1493-8.

12 Maguire P, Faulkner A. How to communicate with cancer patients: 1. Handling bad news and difficult questions. BMF 1988;297:907-9.

\title{
Thrombolytic treatment for recurrent myocardial infarction
}

\author{
Avoid repeating streptokinase or anistreplase
}

The widespread adoption of thrombolytic treatment and widening indications for its use have led to an increasing number of patients presenting to coronary care units who have previously received thrombolytic treatment. In the first year after thrombolytic treatment reinfarction occurs in about $9 \%$ of patients, ${ }^{1}$ and about $20 \%$ of patients admitted with myocardial infarction to a coronary care unit will have had a previous infarction..$^{2-4}$ Both streptokinase and anistreplase are antigenic, and after their administration antibody titres rise within a few days, peak one to two months later, and then slowly recede. High titres of antibodies might potentially be associated with major anaphylactic reactions and may result in ineffective thrombolysis. Many of the patients presenting with recurrent infarction will have received streptokinase and some will have received anistreplase. It is therefore an important issue whether these drugs should be given again.

Most patients have circulating antibodies to streptokinase as a result of a previous streptococcal infection, and for effective thrombolysis the dose of streptokinase must overcome neutralisation by antibody binding. Before Verstraete et $a l$ advocated a standard dosing regimen ${ }^{5}$ streptokinase resistance was tested and the dose modified for each patient. Streptokinase doses greater than 1.25 million units will overcome these antibodies in most patients. The currently recommended dose of 1.5 million units of streptokinase should therefore be effective in all patients except those who have recently received streptokinase or who have had a recent streptococcal infection. ${ }^{5}$

Even though some patients may have high antibody titres, the incidence of allergic reactions is low. In the second international study of infarct survival 8392 patients received streptokinase and none had anaphylactic shock. ${ }^{3}$ In 5860 patients treated in the trial by the Gruppo Italiano per lo Studio Della Streptochinasi nell'Infarto Miocardico there were seven cases of anaphylactic shock but no deaths. ${ }^{2}$

Several measurements can be made to assess the likelihood of reduced fibrinolytic activity with repeat administration of streptokinase or anistreplase. The total streptokinase resistance test measures the inhibition of fibrinolysis and reflects the contribution of $\operatorname{IgG}, \operatorname{IgM}$, and IgE streptokinase antibodies as well as plasmin inhibitors such as $\alpha_{2}$ antiplasmin. The measurement is also influenced by the amounts of fibrinogen and plasminogen present. Assays have been developed for detecting specific $\operatorname{IgG}, \operatorname{Ig} M$, and $\operatorname{IgE}$ antibodies.

Streptokinase resistance titres increase by the fifth day after administration of either streptokinase or anistreplase and remain raised in most patients for at least one year. In a small group of patients Jalihal and Morris showed that at three months all patients had neutralising titres to 1.5 million units of streptokinase. ${ }^{6}$ Massel et al showed that at one year about $70 \%$ ( $95 \%$ confidence interval $48 \%$ to $92 \%$ ) of patients who had previously received streptokinase for acute myocardial infarction had neutralising antibodies to 1.5 million units of streptokinase.

The effect of high antibody titres on lytic efficacy when these drugs are given again is uncertain. Moran et al showed a poor correlation between streptokinase specific IgG measured by radioimmunoassay and the functional streptokinase resistance titre. ${ }^{8}$ In a recent study, in which patients were given streptokinase again within a year, minor allergy was common, but analysis of cardiac enzyme activities and late coronary angiography suggested successful thrombolysis in $70 \%$ of this group. ${ }^{9}$

It remains uncertain which thrombolytic drug is best used in acute infarction. Tissue plasminogen activator is more effective than streptokinase at attaining early arterial patency as judged by a 92 minute angiogram. ${ }^{10}$ Nevertheless, there may be little difference between the drugs in terms of sustained patency, which is the likely mechanism of benefit. ${ }^{11}$ No difference has been detected between the two drugs in their effect on subsequent left ventricular function ${ }^{12}$ or on mortality. ${ }^{13}$ The results of the third international study of infarct survival comparing streptokinase, recombinant tissue plasminogen activator, and anistreplase are awaited. In the mean time streptokinase is the cheapest drug and should be used unless there are doubts about safety or efficacy.

No comparative trials are available to guide the choice of thrombolytic drug for repeat treatment. The risk of major allergic reactions seems to be low when repeat administration is delayed for more than six months, but there are uncertainties about the efficacy of repeat administration. What then can be recommended in the light of our present state of knowledge?

Although the efficacy of repeat administration of streptokinase or anistreplase has not been studied in detail, the high prevalence of raised neutralisation titres at 12 months will probably be associated with decreased thrombolytic efficacy. Treatment shown to be effective should be given and streptokinase or anistreplase should not be administered again within 12 months if non-allergic thrombolytic drugs are available.

Further information is required about antibody titres after 12 months. Meanwhile several strategies could be adopted. Jahil and Morris have recommended measuring neutralisation titres before readministering an individualised dose. ${ }^{6}$ But this may take up to an hour as several dilutions have to be made, and this approach is untenable in the light of the substantial evidence of the benefits of early thrombolytic treatment. ${ }^{2}$ Moreover, an in vitro test may not reflect the 
dynamic in vivo position, with opposing procoagulant and endogenous fibrinolytic activity. An alternative would be to give all patients a higher dose-for example, 3 million units of streptokinase. There will, however, be some patients who would unpredictably have higher titres of neutralising antibodies.

Patients who sustain a second infarction have a higher mortality than those having a first infarction. ${ }^{23}$ While doubt about the effectiveness of readministering streptokinase or anistreplase remains urokinase or tissue plasminogen activator should be given.

Specialist in Cardiovascular Research,

Green Lane Hospital,|Auckland, New Zealand

1 Rivers JT, White HD, Cross DB, Williams BF, Norris RM. Reinfarction after thrombolytic treatment for acute myocardial infarction followed by conservative management: incidence and effect of smoking. 7 Am Coll Cardiol 1990;16:340-8.

2 Gruppo Italiano per lo Studio Della Streptochinasi nell'Infarto Miocardico (GISSI). Effectiveness of intravenous thrombolytic treatment in acute myocardial infarction. Lancet 1986;i:397-402.
3 Second International Study of Infarct Survival Collaborative Group (ISIS-2). Randomised trial of intravenous streptokinase, oral aspirin, both or neither among 17187 cases of suspected acute myocardial infarction: ISIS-2. Lancet 1988;ii:349-60.

4 APSAC (anisoylated plasminogen streptokinase activator complex) Intervention Mortality Study Group. Effect of intravenous APSAC on mortality after acute myocardial infarction: preliminary report of a placebo-controlled clinical trial. Lancet 1989;i:545-9.

Verstraete $M$, Vermylen J, Amery A, Vermylen $C$. Thrombolytic treatment with streptokinase using a standard dosage scheme. BMf 1966;i:454-6.

6 Jalihal S, Morris GK. Antistreptokinase titres after intravenous streptokinase. Lancet 1990;335: 184-5.

7 Massel D, Turpie AGG, Gill JB, O'Dell C, Russell J. Persistence of neutralizing antibodies as one year following IV streptekinase for acute myocardial infarction [Abstract]. Circulation 1990;82: II-1007.

8 Moran DM, Strandring R, Lavender EA, Harris GS. Assessment of anti-streptokinase antibody titres in human sera using a microradioimmunoassay procedure. Thromb, Haemostas (Stuttgart) $1984 \cdot 52 \cdot 281-7$.

9 White HD, Cross DB, Williams BF, Norris RM. Safety and efficacy of readministration of thrombolytic treatment after acute myocardial infarction. Br Heart $\mathcal{f}$ 1990;64:177-81.

10 Chesebro JH, Knatterud G, Roberts R, et al. Thrombolysis in myocardial infarction (TIMI) trial, phase I: a comparison between intravenous tissue plasminogen activator and intravenous streptokinase. Clinical findings through hospital discharge. Circulation 1987;76:142-54

11 White HD. GISSI-2 and the heparin controversy. Lancet 1990;336:297-8.

12 White HD, Rivers JT, Maslowski AH, et al. Effect of intravenous streptokinase as compared with that of tissue plasminogen activator on left ventricular function after first myocardial infarction. NEnglf Med 1989;320:817-21.

13 The International Study Group. In-hospital mortality and clinical course of 20892 patients with suspected acute myocardial infarction tandomised between alteplase and streptokinase with or without heparin. Lancet 1990;336:71-5.

\section{Random breath testing now}

\section{Roadside checkpoints would be no affront to freedom}

Alcohol contributes to an estimated one in 10 road traffic accidents in Britain, accounting for 800 deaths and 22000 casualties each year. ${ }^{12}$ Yet more than a quarter of male drivers admit to having driven at least once in the previous year believing that their blood alcohol concentrations exceeded the legal limit (A Guppy, unpublished communication). And between $10 \mathrm{pm}$ and $3 \mathrm{am} 2 \%$ of drivers are likely to be over the limit. ${ }^{3}$ Certainly, inroads have been made in the problem of drink-driving over the past decade, but just as certainly further deterrents are needed. Random breath testing, proposed in an all party amendment to the Road Traffic Bill, would be one. Based on evidence from other countries, it should work.

Introducing the breathalyser in 1968 substantially reduced drink-driving ${ }^{4}$ because people were frightened of being caught. Now many are not. In a recent survey $42 \%$ of people who admitted to drinking and driving thought that they ran little risk of detection. ${ }^{5}$ As long as people think that they can get away with it penalties won't work-and stopping the offence is clearly better than punishing it. The police agree. "A deterrence based enforcement system," said Mr Peter Joslin, chairman of the traffic committee of the Association of Chief Police Officers, "is far more effective in reducing drinkdrive fatalities than the traditional enforcement model."

At present the police can require a breath test in three circumstances: when the driver is suspected of having alcohol in his or her body, has committed a moving traffic offence, or has been in an accident. They also have a general power to stop any vehicle at any time. According to case law these powers may be combined: a police officer may stop any vehicle to "establish suspicion" that the driver has been drinking, after which a breath test may be required. The police argue that establishing grounds for suspicion before testing should be unnecessary and that they should have unrestricted powers to require a breath test ("unfettered discretion").

The proposed amendment provides for random breath testing at roadside checkpoints. Regulations would permit roadside checks at which either all vehicles or a sample of vehicles could be stopped by a constable in uniform for the administration of breath tests. Roadside checkpoints would be authorised in writing and clearly signposted. As a deterrent to drinking before driving its great virtues are its high visibility and the fact that roadside testing could be encountered anywhere and at any time (though there is no reason why it should not be "targeted"). The Parliamentary Advisory Council for Transport Safety favours the amendment, as do many other experts and members of the public. Experience from abroad, notably in Scandinavia and most of Australia, supports its introduction. In New South Wales, for example, in the first four years of random breath testing the average number of fatal and serious accidents related to alcohol fell by one third. ${ }^{7}$ The hospital and social security savings were over 20 times the initial cost of implementing the scheme. ${ }^{8}$

An argument sometimes used against random breath testing is the low detection rate. ${ }^{6}$ No one, however, is talking about random testing as a substitute for existing procedures: it would be an additional weapon in the armoury. Only in the completely impartial context of roadside checkpoints would the requirement for establishing suspicion be waived. The impartiality of random breath testing is a crucial asset, and the National Council for Civil Liberties supports it. So did $77 \%$ of people interviewed in a government survey last November. ${ }^{9}$

The BMA, among other bodies, is pressing for the measure and is writing to urge MPs to vote for the amendment, on which there could be a vote in the next week or two. It ought to be a free vote. In the short time that remains doctors and other health workers must make their voices heard.

Staff editor, $B M \mathcal{F}$

DAPHNE GLOAG

1 Parliamentary Advisory Council for Transport Safety. Road accidents in focus-3. Why do the happen? London: PACTS, 1990.

2 Department of Transport. Road accidents Great Britain 1989. The casualty report. London: HMSO, 1990:20-5.

3 Sabey BE, Everest JT, Forsyth E. Roadside surveys of drinking and driving. Crowthorne: Transport and Road Research Laboratory, 1988. (TRRL report RR 175.)

4 Department of the Environment. Drinking and driving. Report of the departmental committee. London: HMSO, 1976:1.

Lennox R, Quimby A. A survey of drink-driving behaviour, knowledge and attitudes. Crowthorne: Transport and Road Research Laboratory, 1990. (TRRL Contractor Report 147.)

6 House of Commons. Road traffic (random breath testing). Hansard 1991;22 January: 169-73.

7 Homel R, Carseldine D, Kearns I. Drink-driving countermeasures in Australia. Alcohol, Drugs and Driving 1988;4:113-44.

Arthurson RM. Evaluation of random breath testing. Sydney: Traffic Authority of New South Wales, 1985:20-5.

9 Quimby A, Glendinning R. Perceived effectiveness and favourability toward some road acciden countermeasures: a national suryey. Crowthorne: Transport and Road Research Laboratory, 1990. (TRRL Contractor report 234.) 